Jurnal Mahasiswa BK An-Nur : Berbeda, Bermakna, Mulia

Volume 7 Nomor 3 Tahun 2021

Tersedia Online: https://ojs.uniska-bjm.ac.id/index.php/AN-NUR

p-ISSN. 2460-9722 | e-ISSN. 2622-8297

\title{
EFEKTIFITAS MEDIA EDUKASI GIZI UNTUK PENINGKATAN PENGETAHUAN GIZI REMAJA
}

\author{
Sulistiyawati Murdiningrum ${ }^{1}$, Handayani ${ }^{2}$ \\ ${ }^{1,2}$ Sekolah Pasca Sarjana Universitas Prof DR. Hamka, Fakultas Ilmu Kesehatan Masyarakat, \\ Jalan Warung Jati Barat, Jakarta Selatan, 12740, Indonesia, \\ E-mail:soelis.sm@gmail.com, handayani@uhamka.ac.id/Phone:+6282110901797
}

\begin{abstract}
ABSTRAK
Masalah kurang gizi pada remaja disebabkan oleh faktor langsung dan tidak langsung. Faktor langsung disebabkan disebabkan oleh asupan gizi dan penyakit infeksi dan faktor tidak langsung seperti sosial ekonomi, tingkat pendidikan, pengetahuan ibu dan faktor lingkungan. Kurangnya pengetahuan tentang gizi, anemia, tanda-tanda, dampak dan penanggulangan masalah gizi mengakibatkan kebutuhan gizi remaja tidak terpenuhi. Edukasi gizi tentang rekomendasi gizi seimbang berbasis pangan lokal sangat efektif untuk peningkatan pengetahuan, asupan makanan dan kadar hemoglobin pada remaja putri. Penelitian ini bertujuan untuk mengidentifikasi metode dan media edukasi gizi yang sesuai pada remaja. Metode penelitian yang digunakan Systematic Literature Review (SLR). Data yang digunakan dalam penelitian ini adalah data sekunder yang berasal dari artikel ilmiah nasional periode tahun 2018-2021, basis data yang digunakan yaitu Google Scholar, Pubmed, Science direct Research Gate dengan kata kunci edukasi gizi, media dan remaja. Hasil studi dari 9 artikel yang memenuhi kriteria inklusi didapatkan edukasi gizi yang efektif melalui media sosial, media audiovisual, media konvensional. Dukungan dan pelatihan kelompok educator sebaya menjadi faktor kunci.
\end{abstract}

Kata Kunci : Edukasi Gizi, Remaja, Media, Pengetahuan

\begin{abstract}
The problem of malnutrition in adolescents is caused by direct and indirect factors. Direct factors caused by nutritional intake and infectious diseases and indirect factors such as socioeconomic, education level, mother's knowledge and environmental factors. Lack of knowledge about nutrition, anemia, signs, impacts and overcoming nutritional problems resulted in the nutritional needs of adolescents not being met. Nutrition education about recommendations for balanced nutrition based on local food is very effective for increasing knowledge, food intake and hemoglobin levels in adolescent girls. This study aims to identify appropriate nutrition education methods and media for adolescents. The research method used is Systematic Literature Review (SLR). The data used in this study is secondary data originating from national scientific articles for the period 2018-2021, the database used is Google Scholar, Pubmed, Science direct Research Gate with the keywords nutrition education, media and youth. The results of the study of 9 articles that met the inclusion criteria obtained effective nutrition education through social media, audiovisual media, conventional media. Support and training of peer educator groups is a key factor.
\end{abstract}

Keywords : Nutrition Education, Adolescents, Media, Knowledge

Dipublikasikan Oleh :

UPT Publikasi dan Pengelolaan Jurnal

Universitas Islam Kalimantan Muhammad Arsyad Al-Banjari Banjarmasin 
Sulistiyawati Murdiningrum ${ }^{1}$, Handayani ${ }^{2}$

Jurnal Mahasiswa BK An-Nur : Berbeda, Bermakna, Mulia

Volume 7 Nomor 3 Tahun 2021

Tersedia Online: https://ojs.uniska-bjm.ac.id/index.php/AN-NUR

p-ISSN. 2460-9722 | e-ISSN. 2622-8297

\section{PENDAHULUAN}

Dalam rangka mewujudkan pembangunan Sumber Daya Manusia (SDM) yang berkualitas dan berdaya saing tidak hanya difokuskan pada perbaikan gizi di periode 1000 Hari Pertama Kehidupan (HPK) saja, namun juga pada usia remaja. Remaja adalah SDM yang sangat potensial dalam pembangunan bangsa yang dalam beberapa tahun mendatang komposisi penduduk Indonesia semakin mendekati untuk memperoleh bonus demografi (Badan Perencana Pembangunan Nasional 2021).

Ada tiga beban masalah gizi (triple burden) yang dihadapi oleh Indonesia dan negara-negara berkembang lainnya yaitu stunting, wasting, obesitas dan masalah kekurangan gizi mikro seperti anemia. Jika terus dibiarkan terjadi masalah malnutrisi ini akan meningkatkan kerentanan terhadap penyakit, khususnya terjadinya penyakit tidak menular. (Kementerian Kesehatan RI 2020). Oleh karena itu program perbaikan gizi remaja diarahkan untuk mengatasi tiga beban masalah gizi (triple burden) tersebut (Badan Perencana Pembangunan Nasional 2021).

Berdasarkan hasil Global Nutrition Report tahun 2020, Indonesia belum mengalami perbaikan dalam penurunan prevalensi anemia pada wanita usia $15-49$ tahun yaitu sebesar $28,8 \%$. Selain itu terjadinya penurunan prevalensi kasus stunting $(30,8 \%)$ dan wasting $(10,2 \%)$ remaja perlu mendapat perhatian khusus. Walaupun prevalensi kasus stunting dan wasting Indonesia masih berada diatas rata-rata negara di kawasan Asia. Peningkatan cukup signifikan terjadi pada kasus obesitas anak, remaja dan dewasa laki-laki ataupun perempuan yang dibarengi dengan peningkatan kasus penyakit Diabetes Mellitus (DM) pada dewasa diatas usia 18 tahun (UNICEF 2020).

Berdasarkan hasil Riset Kesehatan Dasar (Riskesdas) Tahun 2018, didapatkan hasil prevalensi status gizi anak pendek dan pendek sebesar 25,75 pada remaja usia 13-15 tahun dan $26,9 \%$ pada remaja usia 16-18 tahun. Selanjutnya untuk prevalensi status gizi kurus dan sangat kurus sebesar 8,7\% pada remaja usia 13-15 tahun dan $8,1 \%$ pada remaja usia $16-18$ tahun. Selain itu prevalensi obesitas sebesar $16 \%$ pada remaja usia 13-15 tahun dan 13,5\% pada remaja usia 16-18 tahun. Bila kondisi ini terus dibiarkan dan berlanjut hingga dewasa dapat menimbulkan masalah kesehatan pada janin yang dikandungnya sehingga rantai intergenerasi masalah gizi tidak dapat diputus. (Kemenkes 2018)

Selain permasalahan status gizi, masalah anemia gizi besi pada remaja cukup tinggi. Berdasarkan hasil Riskesdas 2018, sebanyak 32\% remaja Indonesia menderita anemia. (Kemenkes 2018) Dampak dari anemia dapat menyebabkan rasa letih, sesak nafas, kesulitan berkonsentrasi dan penurunan kinerja kognitif. Kondisi anemia lebih banyak terjadi pada remaja putri, yang jika kondisi ini berlanjut hingga dewasa, mereka beresiko mengalami komplikasi kehamilan dan persalinan seperti perdarahan saat dan setelah persalinan, melahirkan bayi dengan Berat Badan Lahir Rendah (BBLR), lahir prematur atau lahir mati. Selain itu, anak-anak yang lahir dari ibu yang anemia beresiko lebih tinggi untuk mengalami stunting, wasting ataupun underweight.(UNICEF INDONESIA 2020)

Masalah kurang gizi pada remaja disebabkan oleh faktor langsung dan tidak langsung. Faktor langsung disebabkan disebabkan oleh asupan gizi dan penyakit infeksi. (Kasmita 2019) Wamani et al., Fikawati dkk dalam Kasmita (2019), dikatakan bahwa terjadinya kurang gizi akibat dampak beberapa faktor seperti berat lahir dibawah normal, stimulasi dan pengasuhan anak yang kurang tepat, asupan nutrisi yang kurang, infeksi berulang serta faktor lingkungan. Selain faktor langsung, masalah kurang gizi pada remaja disebabkan oleh faktor tidak langsung seperti sosial ekonomi, tingkat pendidikan, pengetahuan ibu dan faktor lingkungan. Kurangnya pengetahuan tentang gizi, anemia, tanda-tanda, dampak dan penanggulangan masalah gizi mengakibatkan kebutuhan gizi remaja tidak terpenuhi. (Putra, Supadi, and Wijaningsih 2019). Tulisan ini dibuat untuk melihat Efektifitas Edukasi Gizi Melalui Media pada Remaja untuk meningkatkan pengetahuan gizinya, dengan mengkaji beberapa jurnal terkait untuk mengidentifikasi metode edukasi gizi dan media yang paling efektif digunakan untuk meningkatkan pengetahuan remaja.

\section{METODE}

Jenis penelitian ini menggunakan metode Sytematic Literatur Review (SLR) yaitu sebuah metode literature review untuk mengidentifikasi, menilai dan menginterpretasi temuan pada suatu topik penelitian untuk menjawab pertanyaan penelitian (research question) yang ditetapkan

Dipublikasikan Oleh :

UPT Publikasi dan Pengelolaan Jurnal

Universitas Islam Kalimantan Muhammad Arsyad Al-Banjari Banjarmasin 
Sulistiyawati Murdiningrum ${ }^{1}$, Handayani ${ }^{2}$

Jurnal Mahasiswa BK An-Nur : Berbeda, Bermakna, Mulia

Volume 7 Nomor 3 Tahun 2021

Tersedia Online: https://ojs.uniska-bjm.ac.id/index.php/AN-NUR

p-ISSN. 2460-9722 | e-ISSN. 2622-8297

sebelumnya (Wahono 2015). Analisa data artikel yang digunakan diperoleh dari internet dengan menggunakan web pencarian jurnal penelitian resmi seperti Google Scholar, Research Gate untuk artikel ilmiah nasional dan internasional dari tahun 2018 - 2021. Strategi yang digunakan untuk pencarian Literatur Review menggunakan kata kunci Edukasi Gizi, Remaja dan Media, yang kemudian dilakukan dengan memilih artikel yang sesuai dengan kriteria inklusi yaitu artikel yang dipublish dalam jurnal ilmiah nasional dan internasional pada kurun waktu tahun 2018 - 2021, metode penelitian kuantitatif (quasi experimental) dan adanya kombinasi metode edukasi, untuk dianalisa isi dan hasil temuan yang didapatkan dalam artikel penelitian tersebut. Proses skrining artikel dilakukan dalam beberapa tahap yaitu, untuk tahap pertama dengan menggunakan kata kunci edukasi gizi diperoleh 2940 artikel. Kemudian proses skrining kedua dengan menggabungkan kedua kata kunci yaitu edukasi gizi remaja diperoleh 1150 artikel. Proses skrining selanjutnya dilakukan dengan menggabungkan ketiga kata kunci yaitu edukasi gizi, remaja dan media diperoleh 923 artikel. Sebanyak 900 artikel dikeluarkan karena kurang relevan karena tidak memenuhi kriteria inklusi, 14 artikel dikeluarkan karena duplikasi artikel yang diterbitkan dalam beberapa jurnal sehingga tersisa 9 jurnal yang memenuhi kriteria untuk dianalisa lebih lanjut.

\section{HASIL DAN PEMBAHASAN}

Dari hasil skrining literatur dengan menggabungkan ketiga kata kunci yaitu edukasi gizi, remaja dan media didapatkan 923 artikel dari data base Google Scholar dan data base Researchgate. Setelah proses skrining seleksi literatur berdasarkan kriteria inklusi dan eksklusi didapatkan 9 Artikel yang memenuhi syarat untuk dianalisis. Seluruh artikel terpilih disajikan pada tabel 1 di bawah ini:

Tabel 1. Hasil Tinjauan Literatur

\begin{tabular}{|c|c|c|c|c|c|c|}
\hline No. & $\begin{array}{l}\text { Nama Penulis / } \\
\text { Tahun Peneliti }\end{array}$ & Nama Jurnal & Judul penelitian & $\begin{array}{c}\text { Variabel yang } \\
\text { diteliti }\end{array}$ & Metode & Hasil \\
\hline 1 & $\begin{array}{l}\text { Sulistiani RP, } \\
\text { Fitriyanti AR, Dewi } \\
\text { L, } 2021\end{array}$ & $\begin{array}{l}\text { Sport and Nutrition } \\
\text { Jurnal, Vol. } 3 \text { No. } 1 \\
-(39-47), \text { Feb } 2021 \\
\text { (Sulistiani, } \\
\text { Fitriyanti, and Dewi } \\
\text { 2021) }\end{array}$ & $\begin{array}{l}\text { Pengaruh Edukasi } \\
\text { Pencegahan } \\
\text { Anemia dengan } \\
\text { Metode Kombinasi } \\
\text { Ceramah dan Team } \\
\text { Game Tournament } \\
\text { (TGT) Pada } \\
\text { Remaja Putri }\end{array}$ & $\begin{array}{l}\text { Dependen : Skor } \\
\text { pengetahuan } \\
\text { Independen : } \\
\text { Karakteristik } \\
\text { responden (BB, } \\
\text { TB, IMT, } \\
\text { LiLa, \% Lemak } \\
\text { tubuh, Kadar } \\
\text { Hb, tekanan } \\
\text { darah), metode } \\
\text { edukasi }\end{array}$ & $\begin{array}{l}\text { Penelitian } \\
\text { kuantitatif } \\
\text { dengan desain } \\
\text { quasi } \\
\text { experimental } \\
\text { pre-post test. }\end{array}$ & $\begin{array}{l}\text { Ada perbedaan } \\
\text { yang signifikan } \\
\text { antara skor } \\
\text { pengetahuan } \\
\text { sebelum dan } \\
\text { sesudah edukasi } \\
\text { dengan metode } \\
\text { ceramah dan TGT. } \\
\text { Dengan metode } \\
\text { tersebut dapat } \\
\text { meningkatkan } \\
\text { pengetahuan } \\
\text { sebesar } 36,1 \% \text {. }\end{array}$ \\
\hline 2 & $\begin{array}{l}\text { Rusdi FY, Rahmy } \\
\text { HA, Helmizar, } 2020\end{array}$ & $\begin{array}{l}\text { Jurnal of Nutrition } \\
\text { Collage, Vol 10, } \\
\text { No. } 1 \text { (31-38), Nov } \\
2020 \\
\text { (Rusdi, Rahmy, and } \\
\text { Helmizar 2020) }\end{array}$ & $\begin{array}{l}\text { Pengaruh Edukasi } \\
\text { Gizi Menggunakan } \\
\text { Instagram } \\
\text { Terhadap } \\
\text { Perubahan Perilaku } \\
\text { Gizi Seimbang } \\
\text { Untuk Pencegahan } \\
\text { Anemia Pada } \\
\text { Remaja Putri di } \\
\text { SMAN } 2 \text { Padang }\end{array}$ & $\begin{array}{l}\text { Dependen : } \\
\text { Peningkatan } \\
\text { pengetahuan } \\
\text { gizi seimbang } \\
\text { Independen : } \\
\text { Usia, media } \\
\text { edukasi }\end{array}$ & $\begin{array}{l}\text { Penelitian } \\
\text { kuantitatif } \\
\text { dengan desain } \\
\text { quasi } \\
\text { experimental } \\
\text { pre-post test } \\
\text { with control } \\
\text { group design }\end{array}$ & $\begin{array}{l}\text { Ada perbedaan } \\
\text { pengetahuan yang } \\
\text { signifikan antara } \\
\text { Instagram dan } \\
\text { kelompok control. } \\
\text { Terdapat } \\
\text { peningkatan } \\
\text { pengetahuan } \\
\text { tentang gizi } \\
\text { seimbang untuk } \\
\text { pencegahan anemia } \\
\text { pada kelompok } \\
\text { Instagram. } \\
\end{array}$ \\
\hline 3 & Sekti RM, Fayasari & Jurnal Ilmiah & Edukasi Gizi & Dependen: & Penelitian & Ada peningkatan \\
\hline
\end{tabular}

Dipublikasikan Oleh :

UPT Publikasi dan Pengelolaan Jurnal

Universitas Islam Kalimantan Muhammad Arsyad Al-Banjari Banjarmasin 
Sulistiyawati Murdiningrum $^{1}$, Handayani $^{2}$

Jurnal Mahasiswa BK An-Nur : Berbeda, Bermakna, Mulia

Volume 7 Nomor 3 Tahun 2021

Tersedia Online: https://ojs.uniska-bjm.ac.id/index.php/AN-NUR p-ISSN. 2460-9722 | e-ISSN. 2622-8297

$\begin{array}{lll}\text { A, 2019 } & \text { Kesehatan, Vol. 1, } & \text { dengan Media } \\ \text { No. 2, pp 77-88 } & \text { Audiovisual } \\ \text { (Sekti and Fayasari } & \text { terhadap Pola } \\ \text { 2019) } & \text { Konsumsi Sayur } \\ & \text { Buah pada Remaja } \\ & \text { SMP di Jakarta } \\ & \text { Timur }\end{array}$

$\begin{array}{ll}\begin{array}{l}\text { Pengetahuan } \\ \text { dan perilaku } \\ \text { konsumsi }\end{array} & \begin{array}{l}\text { kuantitatif } \\ \text { dengan desain } \\ \text { quasi } \\ \text { experimental } \\ \text { pre-post test } \\ \text { Independen : }\end{array} \\ \begin{array}{l}\text { Usia, jenis } \\ \text { kelamin, metode } \\ \text { edukasi }\end{array} & \end{array}$

signifikan pengetahuan dan konsumsi buah sayur setelah intervensi pada kelompok ceramah dan kelompok kombinasi. Tidak ada perbedaan pengetahuan $(\mathrm{p}=0,169)$, konsumsi buah $(\mathrm{p}=0,417)$ dan konsumsi sayur $(\mathrm{p}=0,417)$ antara siswa yang diberikan edukasi gizi dengan media ceramah dan yang diberikan edukasi dengan media ceramah kombinasi video

\begin{tabular}{|c|c|c|c|c|c|c|}
\hline 4 & $\begin{array}{l}\text { Zaki I, Sari HP, } \\
2019\end{array}$ & $\begin{array}{l}\text { Gizi Indonesia, } \\
\text { Journal of The } \\
\text { Indonesian } \\
\text { Nutrition } \\
\text { Association, 42(2): } \\
\text { 111-122 (Zaki and } \\
\text { Sari 2019) }\end{array}$ & $\begin{array}{l}\text { Edukasi Gizi } \\
\text { Berbasis Media } \\
\text { Sosial } \\
\text { Meningkatkan } \\
\text { Pengetahuan dan } \\
\text { Asupan Energi- } \\
\text { Protein Remaja } \\
\text { Putri dengan } \\
\text { Kurang Energi } \\
\text { Kronik (KEK) }\end{array}$ & $\begin{array}{l}\text { Dependen: } \\
\text { Pengetahuan } \\
\text { gizi } \\
\text { Independen : } \\
\text { Usia,domisili, } \\
\text { media edukasi }\end{array}$ & $\begin{array}{l}\text { Penelitian } \\
\text { kuantitatif } \\
\text { dengan desain } \\
\text { quasi } \\
\text { experimental, } \\
\text { rancangan one } \\
\text { group pre test- } \\
\text { post test }\end{array}$ & $\begin{array}{l}\text { Ada perbedaan } \\
\text { pengetahuan gizi, } \\
\text { asupan energi dan } \\
\text { protein sebelum dan } \\
\text { sesudah edukasi } \\
\text { gizi berbasis sosial } \\
\text { media di pedesaan } \\
\text { maupun perkotaan. } \\
\text { Akan tetapi jumlah } \\
\text { peningkatan skor } \\
\text { pengetahuan gizi, } \\
\text { asupan energi dan } \\
\text { protein tidak } \\
\text { berbeda antara } \\
\text { pedesaan dan } \\
\text { perkotaan }\end{array}$ \\
\hline 5 & $\begin{array}{l}\text { Sari D, Vionalita G, } \\
2021\end{array}$ & $\begin{array}{l}\text { VisiKes Jurnal } \\
\text { Kesehatan FK } \\
\text { Universitas Dian } \\
\text { Nuswantono, Vol. } \\
20 \text { (no. 1) (Sari and } \\
\text { Vionalita 2021) }\end{array}$ & $\begin{array}{l}\text { Perbedaan } \\
\text { Pengetahuan } \\
\text { Anemia dan Tablet } \\
\text { Tambah Darah } \\
\text { (TTD) Sebelum } \\
\text { dan Sesudah } \\
\text { Pendidikan } \\
\text { Kesehatan Melalui } \\
\text { Video dan Aplikasi } \\
\text { Quizlet }\end{array}$ & $\begin{array}{l}\text { Dependen: } \\
\text { Pengetahuan } \\
\text { Anemia } \\
\text { Independen: } \\
\text { media edukasi }\end{array}$ & $\begin{array}{l}\text { Penelitian } \\
\text { kuantitatif } \\
\text { dengan desain } \\
\text { quasi } \\
\text { experimental, } \\
\text { rancangan one } \\
\text { group pre test- } \\
\text { post test }\end{array}$ & $\begin{array}{l}\text { Ada perbedaan } \\
\text { yang signifikan } \\
\text { antara pengetahuan } \\
\text { anemia dan tablet } \\
\text { tambah darah } \\
\text { (TTD) sebelum dan } \\
\text { sesudah Pendidikan } \\
\text { Kesehatan melalui } \\
\text { media video dan } \\
\text { aplikasi Quizlet } \\
(\mathrm{p}=0,000)\end{array}$ \\
\hline 6 & $\begin{array}{l}\text { Sari HP, Subardjo } \\
\text { YP, Zaki I, } 2019\end{array}$ & $\begin{array}{l}\text { Indonesian Journal } \\
\text { of Nutrition and }\end{array}$ & $\begin{array}{l}\text { Nutrition } \\
\text { Education, }\end{array}$ & $\begin{array}{l}\text { Dependen : } \\
\text { Pengetahuan }\end{array}$ & $\begin{array}{l}\text { Penelitian } \\
\text { kuantitatif }\end{array}$ & $\begin{array}{l}\text { Adanya } \\
\text { peningkatan kadar }\end{array}$ \\
\hline
\end{tabular}

\section{Dipublikasikan Oleh :}

UPT Publikasi dan Pengelolaan Jurnal 
Sulistiyawati Murdiningrum ${ }^{1}$, Handayani ${ }^{2}$

Jurnal Mahasiswa BK An-Nur : Berbeda, Bermakna, Mulia

Volume 7 Nomor 3 Tahun 2021

Tersedia Online: https://ojs.uniska-bjm.ac.id/index.php/AN-NUR p-ISSN. 2460-9722 | e-ISSN. 2622-8297

\begin{tabular}{|c|c|c|c|c|c|c|}
\hline & & $\begin{array}{l}\text { Dietetics, Vol. 6, } \\
\text { No. 3, 2018: 107- } \\
112 \text { (Sari, Subardjo, } \\
\text { and Zaki 2019) }\end{array}$ & $\begin{array}{l}\text { hemoglobin levels } \\
\text { and nutrition } \\
\text { adolescent girls in } \\
\text { Banyumas District }\end{array}$ & $\begin{array}{l}\text { gizi } \\
\text { Independen: } \\
\text { Usia, kadar } \mathrm{Hb} \text {, }\end{array}$ & $\begin{array}{l}\text { dengan desain } \\
\text { quasi } \\
\text { experimental, } \\
\text { rancangan one } \\
\text { group pre test- } \\
\text { post test } \\
\end{array}$ & $\begin{array}{l}\text { hemglobin dan skor } \\
\text { pengetahuan } \\
\text { responden setelah } 6 \\
\text { kali pertemuan } \\
\text { dalam waktu 1,5 } \\
\text { bulan }\end{array}$ \\
\hline 7 & $\begin{array}{l}\text { Jafar N, Indriasari } \\
\text { R, Syam A, Kurniati } \\
Y, 2018\end{array}$ & $\begin{array}{l}\text { Media Gizi Pangan, } \\
\text { Vo. 25, Edisi } 1 \\
\text { (Jafar et al. 2018) }\end{array}$ & $\begin{array}{l}\text { Pelatihan Edukator } \\
\text { Sebaya dan } \\
\text { Pengetahuan Gizi } \\
\text { Seimbang Pada } \\
\text { Siswa di SMUN } 16 \\
\text { Makassar }\end{array}$ & $\begin{array}{l}\text { Dependen : } \\
\text { Pengetahuan } \\
\text { edukator sebaya } \\
\text { Independen : } \\
\text { Usia, jenis } \\
\text { kelamin, agama, } \\
\text { suku, status gizi }\end{array}$ & $\begin{array}{l}\text { Penelitian studi } \\
\text { intervensi, data } \\
\text { pengetahuan } \\
\text { responden } \\
\text { diukur dengan } \\
\text { kuesioner }\end{array}$ & $\begin{array}{l}\text { Pelatihan edukator } \\
\text { sebaya dengan } \\
\text { modul edukasi gizi } \\
\text { yang dikembangkan } \\
\text { pada studi ini } \\
\text { berhasil } \\
\text { meningkatkan } \\
\text { pengetahuan } \\
\text { responden tentang } \\
\text { gizi seimbang } \\
\text { sebesar 52,5\% } \\
\end{array}$ \\
\hline 8. & $\begin{array}{l}\text { Wardhani DA, } \\
\text { Nissa C, } \\
\text { Setyaningrum YI, } \\
2021\end{array}$ & $\begin{array}{l}\text { Jurnal Gizi Unimus } \\
\text { Vo. } 10 \text { No. } 1 \text { 2021: } \\
\text { 31-37 (Wardhani, } \\
\text { Nissa, and } \\
\text { Setyaningrum 2021) }\end{array}$ & $\begin{array}{l}\text { Peningkatan } \\
\text { Pengetahuan } \\
\text { Remaja Putri } \\
\text { Melalui Edukasi } \\
\text { Media Whatsapp } \\
\text { Group }\end{array}$ & $\begin{array}{l}\text { Dependen : } \\
\text { Pengetahuan } \\
\text { remaja putri } \\
\text { Independen: } \\
\text { Media edukasi }\end{array}$ & $\begin{array}{l}\text { Penelitian } \\
\text { kuantitatif } \\
\text { dengan desain } \\
\text { quasi } \\
\text { experimental, } \\
\text { rancangan one } \\
\text { group pre test- } \\
\text { post test }\end{array}$ & $\begin{array}{l}\text { Ada pengaruh } \\
\text { edukasi gizi } \\
\text { terhadap } \\
\text { peningkatan } \\
\text { pengetahuan remaja } \\
\text { putri, akan tetapi } \\
\text { tidak berpengaruh } \\
\text { terhadap } \\
\text { peningkatan sikap } \\
\text { remaja putri }\end{array}$ \\
\hline 9. & $\begin{array}{l}\text { Krisdiani AF, } \\
\text { Sufyan DL, Ilmi } \\
\text { IMB, Syah MNH, } \\
2020\end{array}$ & $\begin{array}{l}\text { Jurnal Ikesma } \\
\text { Volume 16 Nomor } \\
\text { 2, 2020: 95-102 } \\
\text { (Krisdiani et al. } \\
\text { 2020) }\end{array}$ & $\begin{array}{l}\text { Pengaruh Edukasi } \\
\text { Melalui Twitter } \\
\text { Thread Terhadap } \\
\text { Pengetahuan Gizi } \\
\text { Seimbang Remaja } \\
\text { di SMP Harjamukti } \\
\text { Depok }\end{array}$ & $\begin{array}{l}\text { Dependen : } \\
\text { Pengetahuan } \\
\text { Gizi } \\
\text { Independen: } \\
\text { Umur, jenis } \\
\text { kelamin, status } \\
\text { gizi, } \\
\text { Pendidikan, } \\
\text { pekerjaan, } \\
\text { penghasilan, } \\
\text { media edukasi }\end{array}$ & $\begin{array}{l}\text { Penelitian } \\
\text { kuantitatif } \\
\text { dengan desain } \\
\text { quasi } \\
\text { experimental, } \\
\text { rancangan one } \\
\text { group pre test- } \\
\text { post test }\end{array}$ & $\begin{array}{l}\text { Adanya } \\
\text { peningkatan } \\
\text { pengetahuan } \\
\text { sebelum dan } \\
\text { sesudah diberikan } \\
\text { edukasi melalui } \\
\text { twitter thread. } \\
\text { Tidak ada } \\
\text { hubungan } \\
\text { perubahan } \\
\text { pengetahuan } \\
\text { dengan perubahan } \\
\text { status gizi } \\
\text { responden } \\
(\mathrm{P}=0,547 ; \mathrm{r}=0,085)\end{array}$ \\
\hline
\end{tabular}

Dipublikasikan Oleh :

UPT Publikasi dan Pengelolaan Jurnal

Universitas Islam Kalimantan Muhammad Arsyad Al-Banjari Banjarmasin 


\section{Sulistiyawati Murdiningrum ${ }^{1}$, Handayani $^{2}$ \\ Jurnal Mahasiswa BK An-Nur : Berbeda, Bermakna, Mulia \\ Volume 7 Nomor 3 Tahun 2021 \\ Tersedia Online: https://ojs.uniska-bjm.ac.id/index.php/AN-NUR \\ p-ISSN. 2460-9722 | e-ISSN. 2622-8297}

Media promosi kesehatan adalah semua sarana atau upaya yang dilakukan untuk menampilkan pesan atau informasi oleh komunikator melalui berbagai saluran media kepada komunikan. Pesan yang akan disampaikan bisa beragam sesuai dengan kebutuhan informasi yang akan akan disampaikan. Salah satu nya adalah Pendidikan gizi. Pendidikan gizi pada remaja sangat penting untuk. Memberikan pengertian dan bekal untuk memilah makanan, perilaku diet gizi seimbang dan aktifitas fisik yang cukup untuk mencapai Kesehatan yang optimal. Pendidikan gizi dapat bersifat langsung memalui tatap muka dengan penyuluhan individu dan kelompok ataupun tidak langsung melalui media massa, buku bacaab, elektronik, leaflet dan sebagainya. (Mahdali, Indriasari, and Thaha 2013).

Berdasarkan studi literatur artikel yang didapatkan tentang media edukasi gizi didapatkan dalam 9 artikel nasional yang sesuai dengan kriteria inklusii dan topik yang dibahas oleh penulis. Menurut (Sulistiani et al. 2021) salah satu cara meningkatkan pengetahuan gizi adalah dengan edukasi gizi melalui kombinasi metode ceramah dan Teams Games Tournament (TGT) terkait materi pencegahan anemia pada remaja putri. TGT adalah jenis tipe pembelajaran kooperatif dalam kelompok kecil (5-6 orang per kelompok). Dari hasil beberapa waktu edukasi diperoleh adanya peningkatan pengetahuan sebesar $36,1 \%$ antara sebelum dan sesudah edukasi pada remaja putri. Dan metode ini cukup efektif dan interaktif diterapkan pada jumlah sampel yang cukup besar. Hanya untuk output perubahan perilaku dibutuhkan periode edukasi secara berkala. Sejalan dengan penelitian (Sari et al. 2019) Pendidikan gizi tentang materi anemia secara berkala selama 1,5 bulan terbukti secara signifikan adanya peningkatan kadar hemglobin dan skor pengetahuan responden setelah 6 kali pertemuan sebesar $90 \%$. Dalam literatur lain dikatakan bahwa metode pelatihan educator sebaya dengan model edukasi gizi terbukti efektig meningkatkan pengetahuan gizi remaja menjadi $70 \%$ (Jafar et al. 2018).

Pengunaan media audio visual, video dan games masih juga terbukti efektif untuk meningkatkan pengetahuan gizi remaja. Sesuai penelitian (Sekti and Fayasari 2019) yang menggunakan metode kombinasi ceramah atau penyuluhan dan pemutaran video untuk edukasi konsumsi buah dan sayur terbukti dapat meningkatkan pengetahuan remaja untuk konsumsi buah dan sayur. Sejalan dengan penelitian (Sari and Vionalita 2021) bahwa pemutaran video animasi tentang anemia dan konsumsi tablet tambah darah
(TTD) lalu dikombinasikan dengan aplikasi Quizlet terbukti dapat secara signifikan meningkatkan pengetahuan remaja tentang anemia.

Seiring dengan perkembangan teknologi dan arus informasi pengunaan media social sebagai media edukasi mulai menjadi pilihan dan terbukti juga efektif dalam penyebarluasan informasi gizi dalam meningkatkan pengetahuan. Dalam penelitian (Rusdi et al. 2020) memanfaatkan aplikasi instagram dan whatsapp untuk edukasi gizi seimbang sebanyak 9 kali dalam 18 hari pada remaja. Didapatkan hasil bahwa media Instagram terbukti lebih efektif untuk meningkatkan pengetahuan, sikap dan Tindakan gizi lebih baik daripada media whatsapp. Hal ini karena dimungkinkan Instagram lebih interaktif dan fitur yang lebih baik bila dibandingkan dengan whatsapp. Hal ini sejalan dengan hasil penelitian lainnya oleh (Wardhani et al. 2021) didapatkan hasil bahwa penggunaan media whatsapp group sebagai media edukasi hanya untuk meningkatkan pengetahuan tetapi tidak dengan sikap dan tindakan. Selain intagram dan whatsapp, pengunaan media social lainnya yang digunakan adalah twitter. Menurut (Krisdiani et al. 2020), fitur thread pada twitter dapat digunakan sebagai media edukasi gizi seimbang, dalam 6 minggu periode edukasi adanya peningkatan rata-rata pengetahuan sebesar 7,97. Hanya untuk perubahan sikap dan Tindakan dibutuhkan waktu yang cukup lama lagi, yaitu sekitar 12 minggu. Dan dalam penelitian (Zaki and Sari 2019) membuktikan bahwa penggunaan media social di lingkup kota dan desa tidak terdapat perbedaan peningkatan skor pengetahuan. Artinya bahwa penggunaan media social di kalangan remaja sudah cukup meluas, tidak hanya terbatas di lingkup kota saja tapi remaja di pedesaan pun sudah cukup familiar.

Pengembangan media pendidikan gizi menjadi sangat penting dilakukan dan merupakan hal yang sangat penting untuk terus dilakukan secara berkesinambungan mengingat remaja sebagai kelompok yang rentan dan labil masih membutuhkan informasi yang menarik, interaktif dan terbarukan. Dari hasil pembahasan dari literatur yang didapat, dapat disimpulkan bahwa urutan media yang paling efektif untuk edukasi gizi adalah Media Sosial Intagram, Whatsapp, Twitter, selanjutnya adalah Media Kombinasi antara Ceramah dengan Video/Games/Quiz dan terakhir adalah ceramah konvensional. Dukungan kelompok sebaya menjadi salah satu faktor kunci yang dapat memberikan daya ungkit yang sangat besar untuk keberhasilan program edukasi gizi bagi remaja, mengingat di usia remaja,

Dipublikasikan Oleh :

UPT Publikasi dan Pengelolaan Jurnal

Universitas Islam Kalimantan Muhammad Arsyad Al-Banjari Banjarmasin 
Sulistiyawati Murdiningrum ${ }^{1}$, Handayani ${ }^{2}$

Jurnal Mahasiswa BK An-Nur : Berbeda, Bermakna, Mulia

Volume 7 Nomor 3 Tahun 2021

Tersedia Online: https://ojs.uniska-bjm.ac.id/index.php/AN-NUR

p-ISSN. 2460-9722 | e-ISSN. 2622-8297

teman sebaya lebih banyak memberikan pengaruh untuk sikap dan Tindakan yang akan diambil. Untuk penelitian selanjutnya kombinasi metode edukasi dan media yang digunakan menjadi lebih efektif untuk meningkatkan pengetahuan gizi remaja.

\section{REFERENSI}

Badan Perencana Pembangunan Nasional. 2021. "Tantangan Gizi Remaja Dalam Menghadapi Pandemi Covid-19." Cegah Stunting.Id.

Jafar, Nurhaedar, Rahayu Indriasari, Aminuddin Syam, and Yessy Kurniati. 2018. "Pelatihan Edukator Sebaya Dan Pengetahuan Tentang." Media Gizi Pangan 25:1-10.

Kasmita. 2019. "Aplikasi Lesson Study (Als) Untuk Keberhasilan Edukasi Pencegahan Stunting." Doctoral Thesis, Universitas Andalas.

Kemenkes. 2018. "RISKESDAS 2018." Badan Penelitian Dan Pengembangan Kesehatan.

Kementerian Kesehatan RI. 2020. "Gizi Saat Remaja Tentukan Kualitas Keturunan.” Kementerian Kesehatan Republik Indonesia. Retrieved (https://www.kemkes.go.id/article/view/200126 00004/gizi-saat-remaja-tentukan-kualitasketurunan.html).

Krisdiani, Ade Fatma, Dian Luthfiana Sufyan, Ibnu Malkan Bakhrul Ilmi, and Muhammad Nur Hasan Syah. 2020. "Pengaruh Edukasi Melalui Twitter Thread Terhadap Pengetahuan Gizi Seimbang Remaja Di SMP Harjamukti Depok." Ikesma 16(2):95. doi: 10.19184/ikesma.v16i2.18804.

Mahdali, Mohamad Ikbal, Rahayu Indriasari, and Ridwan Thaha. 2013. "Efek Edukasi Gizi Terhadap Pengetahuan, Sikap Serta Perubahan Perilaku Remaja Obesitas Di Kota Gorontalo." Gorontalo Journal of Public Health 1-12.

Putra, Rizqi Widyantori Hasanah, J. Supadi, and Wiwik Wijaningsih. 2019. "PENGARUH PEMBERIAN EDUKASI GIZI TERHADAP PENGETAHUAN DAN SIKAP MENGENAI ANEMIA PADA REMAJA PUTRI." JURNAL RISET GIZI 7(2). doi: 10.31983/jrg.v7i2.5220.

Rusdi, Faza Yasira, Hafifatul Auliya Rahmy, and Helmizar. 2020. "Pengaruh Edukasi Gizi Menggunakan Instagram Terhadap Perubahan Perilaku Gizi Seimbang Untuk Pencegahan Anemia Pada Remaja Putri Di Sma N 2 Kota Padang." Fakultas Kesehatan Masyarakat Universitas Andalas Padang, 2020 10(November 2020):31-38.

Sari, Devita, and Gisely Vionalita. 2021. "Perbedaan
Pengetahuan Anemia Dan Tablet Tambah Darah (TTD) Sebelum Dan Sesudah Pendidikan Kesehatan Melalui Media Video Dan Aplikasi Quizlet." Jurnal Kesehatan Visikes 20(1).

Sari, Hesti Permata, Yovita Puri Subardjo, and Ibnu Zaki. 2019. "Nutrition Education, Hemoglobin Levels, and Nutrition Knowledge of Adolescent Girls in Banyumas District." Jurnal Gizi Dan Dietetik Indonesia (Indonesian Journal of Nutrition and Dietetics) 6(3). doi: 10.21927/ijnd.2018.6(3).107-112.

Sekti, Rike Minati, and Adhila Fayasari. 2019. "Edukasi Gizi Dengan Media Audiovisual Terhadap Pola Konsumsi Sayur Buah Pada Remaja SMP Di Jakarta Timur.” Jurnal Ilmiah Kesehatan 1(2):77-88. doi: 10.36590/jika.v1i2.15.

Sulistiani, Ria Purnawian, Addina Rizky Fitriyanti, and Luthfia Dewi. 2021. "Pengaruh Edukasi Pencegahan Anemia Dengan Metode Kombinasi Ceramah Dan Team Game Tournament Pada Remaja Putri." Sport and Nutritional Journal 3, No. 1(56):39-47.

UNICEF. 2020. Global Nutrition Report: Country Nutrition Profiles.

UNICEF INDONESIA. 2020. “Upaya Remaja Mencegah Anemia." UNICEF INDONESIA.

Wahono, Satria Romi. 2015. "A Systematic Literature Review of Software Defect Prediction: Research Trends, Datasets, Methods and Frameworks. J Softw Eng. Vol. 1, No. o Title." Journal of Software Engineering, Vol. 1, No. 1, April 2015 Vol. 1.

Wardhani, Dwi Aulia, Choirun Nissa, and Yahmi Ira Setyaningrum. 2021. "Peningkatan Pengetahuan Remaja Putri Melalui Edukasi Gizi Menggunakan Media Whatsapp Group." 10(1):31-37.

Zaki, Ibnu, and Hesti Permata Sari. 2019. "Edukasi Gizi Berbasis Media Sosial Meningkatkan Pengetahuan Dan Asupan Energi- Protein Remaja Putri Dengan Kurang Energi Kronik (Kek)." Gizi Indonesia 42(2):111. doi: 10.36457/gizindo.v42i2.469.

Dipublikasikan Oleh :

UPT Publikasi dan Pengelolaan Jurnal

Universitas Islam Kalimantan Muhammad Arsyad Al-Banjari Banjarmasin 